\title{
CORRELATING TWO QUESTIONNAIRES: VESTIBULAR ACTIVITIES AND PARTICIPATION (VAP) AND DIZZINESS HANDICAP INVENTORY (DHI)
}

\author{
Sharda A. Sarda, C. S. Vanaja \\ Department of Audiology and Speech Language Pathology, Bharati Vidyapeeth Deemed University's Medical \\ Hospital, Pune, India \\ Corresponding author: Sharda Sarda, Department of Audiology and Speech Language Pathology, Bharati \\ Vidyapeeth Deemed University's Medical Hospital, 16/2 Bharirathi Building, near Amba Mata Mandir, \\ Sukhsagarnagar, Katraj, Pune-411046, India, e-mail: sharada.sarda@gmail.com. Tel. +0011-9764310600
}

\begin{abstract}
Background: Dizziness is known to affect the quality of life, irrespective of its underlying pathology. The Dizziness Handicap Inventory (DHI) is a commonly used questionnaire to assess self-perceived handicap among individuals with dizziness. However, the International Classification of Functioning, Disability and Health (ICF), emphasises the assessment of activity limitations and participation restrictions. A recently developed questionnaire, the Vestibular Activities and Participation (VAP), is based on the ICF model and has been found to be a valid and reliable tool. The present study was undertaken to explore which items of DHI relate to vestibular activity limitations and participation restrictions by investigating the correlations between items of DHI and VAP.
\end{abstract}

Material and methods: This was a prospective study involving 56 individuals whose primary complaint was dizziness due to vestibular pathology. All had undergone detailed audio-vestibular tests prior to administration of a Marathi translation of the DHI and VAP questionnaires.

Results: 12 of the 25 questions on the DHI showed strong and moderate correlations with the total VAP score ( $r=0.48-0.68$, $p<0.05)$, while 8 questions showed significant but weak correlation $(r=0.34-0.44, p<0.05)$, and 5 questions showed no correlation $(r=0.27-0.29, p>0.05)$. The results indicate that less than half the 25 questions covering the physical, functional, or emotional domains of DHI reflect activity limitations or participation restriction in day-to-day life.

Conclusions: The results indicate that responses to only some of the items of DHI are important when studying activity limitations and participation restrictions of people with dizziness. These particular items may be a better indicator of the effect of dizziness on the quality of life, and hence could be most relevant when reporting post-therapeutic improvement in quality of life.

Key words: dizziness $\bullet$ DHI $\bullet$ VAP $・$ ICF

\section{COMPARACIÓN DE DOS CUESTIONARIOS: VESTIBULAR ACTIVITIES AND PARTICIPATION (VAP) Y DIZZINESS HANDICAP INVENTORY (DHI)}

\begin{abstract}
Resumen
Introducción: Los mareos afectan a la calidad de vida, independientemente de la enfermedad del paciente. Dizziness Handicap Inventory (DHI) es un cuestionario usado habitualmente para evaluar la sensación de deficiencia en personas con mareos. Otro cuestionario, International Classification of Functioning, Disability and Health (ICF) pone hincapié en la evaluación de la limitación de actividad y funcionamiento. El cuestionario creado hace poco, Vestibular Activities and Participation (VAP), basado en el modelo ICF resultó una herramienta autorizada y fidedigna. El estudio fue realizado con el fin de un análisis cuyos elementos de DHI están relacionados con la limitación de la actividad de la hipófisis y con la limitación de funcionamiento a través del estudio de la correlación entre los elementos DHI y VAP.
\end{abstract}

Material y métodos: El examen prospectivo concierne a 56 paciente que se quejaban sobre todo se mareos relacionados con la enfermedad vestibular. Todos fueron sometidos a estudios audio-vestibulares y luego rellenaron los cuestionarios DHI y VAP en marthi.

Resultados: En 12 de 25 preguntas en DHI se observaron correlaciones relevantes y medias con un resultado VAP total $(r=0.48-0.68, p<0.05)$, mientras que en 8 preguntas se observaron una correlación relevante, pero débil $(r=0.34-0.44, p<0.05)$, y en 5 preguntas no se observaron correlaciones $(r=0.27-0.29, p>0.05)$. 
Los resultados muestran que menos de la mitad de las 25 preguntas DHI concernientes a los campos físicos, funcionales y emocionales reflejan limitaciones de actividad y participación en la vida cotidiana.

Resultados: Los resultados muestran que las respuestas a sólo algunas posiciones en DHI son importantes desde el punto de vista de los estudios de la limitación de actividad y funcionamiento en personas con mareos. Algunas posiciones pueden ser un indicador mejor de la influencia de los mareos en la calidad de la vida y por eso pueden se adecuadas durante la recogida de información sobre la mejora de la calidad después de una lesión.

Palabras clave: mareos $\bullet$ DHI $\bullet$ VAP $・$ ICF

\section{СРАВНЕНИЕ ДВУХ АНКЕТ: VESTIBULAR ACTIVITIES AND PARTICIPATION (VAP) И DIZZINESS HANDICAP INVENTORY (DHI)}

\section{Изложение}

Введение: головокружения влияют на качество жизни, независимо от главного заболевания пациента. Dizziness Handicap Inventory (DHI) - это повсеместно использованная анкета для оценки самочувствия нарушений у людей с головокружениями. Другая анкета, International Classification of Functioning, Disability and Health (ICF), делает упор на оценку ограничений активности и функционирования. Недавно созданная анкета, Vestibular Activities and Participation (VAP), основанная на модели ICF, оказалась достоверным и надежным инструментом. Исследование проведено с целью анализа, которые элементы DHI связаны с ограничением активности предсердий и ограничением функционирования посредством исследования корреляции между элементами DHI и VAP.

Материал и методы: Проспективное исследование, охватывающее 56 пациентов, которые жаловались на головокружение, связанное с заболеванием предсердий. Все были подвержены тщательным аудио предсердным исследованиям, а затем они заполнили анкеты DHI и VAP на языке маратхи.

Результаты: В 12 из 25 вопросов в DHI замечена существенная и средняя корреляция с полным результатом $(r=0.48-0.68, p<0.05)$, тогда как в 8 вопросах замечена существенная, но слабая корреляция $(r=0.34-0.44, p<0.05)$, а в 5 вопросах корреляции не замечено $(r=0.34-0.44, p<0.05)$. Результаты показывают, что меньше чем половина из 25 вопросов DHI, касающихся физических, функциональных и эмоциональных областей, отображает ограничения активности и участия в жизнедеятельности.

Итоги: Результаты показывают, что важными являются ответы только на некоторые положения в DHI с точки зрения исследований ограничений активности и функционирования у людей с головокружением. Некоторые положения могут быть лучшим указателем влияния головокружения на качество жизни и поэтому они могут быть соответствующие при сборе информации об улучшении качества жизни после травмы.

Ключевые слова: головокружение • DHI • VAP • ICF

\section{PORÓWNANIE DWÓCH KWESTIONARIUSZY: VESTIBULAR ACTIVITIES AND PARTICIPATION (VAP) ORAZ DIZZINESS HANDICAP INVENTORY (DHI)}

\section{Streszczenie}

Wprowadzenie: Zawroty głowy wpływają na jakość życia, bez względu na główną chorobę pacjenta. Dizziness Handicap Inventory (DHI) jest powszechnie używanym kwestionariuszem do oceny samoodczuwania upośledzenia u osób z zawrotami głowy. Inny kwestionariusz, International Classification of Functioning, Disability and Health (ICF), kładzie nacisk na ocenę ograniczenia aktywności i funkcjonowania. Niedawno stworzony kwestionariusz, Vestibular Activities and Participation (VAP), oparty na modelu ICF, okazał się miarodajnym i wiarygodnym narzędziem. Badanie zostało przeprowadzone w celu analizy, które elementy DHI wiążą się z ograniczeniem aktywności przedsionkowej i ograniczeniem funkcjonowania poprzez zbadanie korelacji pomiędzy elementami DHI i VAP.

Materiał i metody: Badanie prospektywne obejmujące 56 pacjentów, którzy skarżyli się głównie na zawroty głowy związane $\mathrm{z}$ chorobą przedsionkową. Wszyscy zostali poddani dokładnym badaniom audio-przedsionkowym a następnie wypełnili kwestionariusze DHI i VAP w języku marthi.

Wyniki: W 12 z 25 pytań w DHI zauważono istotne i średnie korelacje z całkowitym wynikiem VAP $(r=0.48-0.68, p<0.05)$, podczas gdy przy 8 pytaniach zauważono korelację istotną ale słabą $(r=0.34-0.44, p<0.05)$, a 5 pytań nie wykazało korelacji 
$(r=0.27-0.29, p>0.05)$. Wyniki wskazują, że mniej niż połowa z 25 pytań DHI dotyczących fizycznych, funkcjonalnych i emocjonalnych obszarów odzwierciedla ograniczenia aktywności i uczestniczenia w działaniach w codziennym życiu.

Wnioski: Wyniki wskazują, że odpowiedzi do tylko niektórych z pozycji w DHI są ważne z punku widzenia badań nad ograniczeniem aktywności i funkcjonowania u osób z zawrotami głowy. Niektóre pozycje mogą być lepszym wskaźnikiem wpływu zawrotów głowy na jakość życia i dlatego mogą być właściwe podczas zbierania informacji o postępie jakości życia po urazie.

Słowa kluczowe: zawroty głowy • DHI • VAP • ICF

\section{Background}

Dizziness is a symptom of many different medical conditions. Irrespective of the causes and underlying health conditions, dizziness has adverse effects on the quality of life and activities of daily living in several ways. It may limit certain head and body movements, or affect professional, domestic, social, and/or leisure activities [1,2]. As a result, people with dizziness become dependent on others and may develop emotional reactions such as fear, depression, anxiety, and withdrawal [3].

Many scales or questionnaires are available to measure the quality of life and activities of daily living in individuals with dizziness. The Dizziness Handicap Inventory (DHI) developed by Jacobson and Newman in 1990 [4] is one such inventory which covers three domains: physical, functional, and emotional. Jacobson and Newman claim test-retest reliability of the DHI as 0.92 [4]. DHI has also been found to be very useful in measuring improvement after vestibular rehabilitation in a person suffering dizziness [5-7].

Perez et al. (2001) analysed the different dimensions of disability and handicap assessed by DHI's 25 questions by using principal component analysis (PCA) [8]. The dimensions obtained were correlated with UCLA-DQ, a dizziness questionnaire developed by the University of California, Los Angeles, as a tool to summarize a person's dizziness characteristics and impact on the quality of life. The results revealed that 7 questions in DHI's functional domain and 7 questions in its emotional domain were grouped as a handicap factor, while the rest of the 11 questions covering the physical, functional, and emotional domains were clustered together as a vestibular disability factor. Furthermore, the frequency and severity of vestibular disorders gauged by the UCLADQ scale were strongly associated with the handicap factor of DHI and only weakly with the vestibular disability factor.

Similarly, in 2010 Kurre et al. [9] explored the structure of DHI based again on PCA. They also studied its association with functional disability as well as emotional reactions by using UCLA-DQ and the Hospital Anxiety and Depression Scale (HADS). Using PCA, DHI was found to be produce four factors: factor one was the effect of dizziness/unsteadiness on emotion and participation; while the second, third, and fourth factors were, respectively, specific activity provoking dizziness, self-perceived walking ability, and feeling of postural stability (along with dependence on others). Correlation analysis revealed that the functional and emotional domains of DHI and items in the first, third, and fourth factors had good correlations with UCLA-DQ. These factors were proposed to be indicative of participation restriction and activity limitation components of the
ICF [10]. Many items from the physical domain had higher loading for the second factor; however, the second factor showed only a poor correlation with UCLA-DQ [9]

It can be construed from these studies that only certain items of DHI correlate significantly with the quality of life or with vestibular activity limitations and participation restrictions. However, there are a dearth of studies investigating the relationship of each item of the DHI with an ICF-based scale which gauges participation restriction under varying contextual and environmental conditions. One recently developed questionnaire, the Vestibular Activities and Participation measure developed in 2012 by Alghwiri and colleagues [11], is based on the ICF model and has been found to be a valid and reliable measure to assess the consequences of dizziness in terms of participation restrictions and functioning in day-to-day life.

Correlating DHI items with VAP can assist the clinician to know which questions of DHI are directly linked with the activity limitations and participation restrictions, as per the ICF model. Thus the primary objective of the present study was to investigate the association of DHI items with the ICF-based VAP scale. Moreover, knowledge of which questions of DHI reflect activity limitations and participation restrictions can help the clinician to track these aspects and trace progress pre and post vestibular rehabilitation.

The specific objectives of the study were to assess the degree of handicap in individuals with dizziness using a Marathi translation of DHI; to assess the level of activities and participation in individuals with dizziness using a Marathi translation of VAP; and finally to investigate if there is any association between the items of DHI and activity limitations and participation restrictions.

\section{Material and methods}

This was a prospective study involving 56 individuals whose primary complaint was dizziness due to vestibular pathology. All the participants had been investigated in detail by a physician and an otorhinolaryngologist. Vestibular assessment carried out in the department of audiology included a detailed case history, pure tone audiometry, videonystagmography, and recording of vestibular evoked myogenic potentials. Only individuals who had dizziness due to vestibular pathology were considered for the study. All participants were native speakers of Marathi, an Indoaryan language spoken in the state of Maharashtra, India.

\section{Test procedures}

A Marathi version of both questionnaires - the Dizziness Handicap Inventory (DHI) and the Vestibular Activities 
Table 1. Participants and their vestibular test results

\begin{tabular}{|c|c|c|c|c|c|}
\hline $\begin{array}{l}\text { Provisional } \\
\text { diagnosis }\end{array}$ & $\begin{array}{l}\text { Vestibular dysfunction as } \\
\text { indicated on VNG \& VEMP }\end{array}$ & $\begin{array}{l}\text { Number of } \\
\text { participants }\end{array}$ & $\begin{array}{c}\text { Age } \\
\text { (years) }\end{array}$ & Gender & $\begin{array}{l}\text { Pure tone average } \\
\text { (dB HL) }\end{array}$ \\
\hline \multirow{2}{*}{ BPPV } & Unilateral & 14 & $50-72$ & 9 female, 5 male & $18-60$ \\
\hline & Bilateral & 6 & $35-76$ & 3 male, 3 female & $20-35$ \\
\hline \multirow{2}{*}{$\begin{array}{l}\text { Unspecified } \\
\text { vestibular } \\
\text { pathology }\end{array}$} & Unilateral & 9 & $40-56$ & 6 female, 4 male & $20-40$ \\
\hline & Bilateral & 7 & $46-70$ & 4 male, 3 female & $18-40$ \\
\hline \multirow{2}{*}{$\begin{array}{l}\text { Meniere's } \\
\text { disease }\end{array}$} & Unilateral & 11 & $20-46$ & 8 female, 3 male & $20-55$ \\
\hline & Bilateral & 4 & $30-60$ & 3 female, 1 male & $25-70$ \\
\hline $\begin{array}{l}\text { Central } \\
\text { pathology }\end{array}$ & Bilateral & 5 & $60-75$ & 2 female, 3 male & $25-30$ \\
\hline
\end{tabular}

and Participation (VAP) scale - was administered via an interview.

The Vestibular Activities and Participation (VAP) scale was developed by Alghwiri et al. based on the ICF model [11]. This measure evaluates the effect of dizziness and/or balance problems on an individual's ability to perform activity and participate in tasks. Responses to each of 34 questions are rated on a scale of 0 to 4 (no difficulty $=0$, mild difficulty $=1$, moderate difficulty $=2$, severe difficulty $=3$, and unable to do the task $=4$ ). The total score is obtained by adding the ratings for each question and dividing by 34 . Thus the total score ranges from 0.0 to 4.0 .

The Dizziness Handicap Inventory (DHI) developed by Jacobson and Newman [4] has three subscales and a total of 25 questions. Each question provides a choice of three responses: yes ( 4 points), sometimes ( 2 points), or no ( 0 points). The maximum possible score is 100: the sum of a maximum score of 36 for the emotional scale ( 9 items), 36 for the functional scale ( 9 items), and 28 for the physical scale (7 items).

Both scales have been adapted to Marathi using a forward and backward translation procedure in which five individuals proficient in both languages were asked to validate the translated versions of each questionnaire.

A pilot study was carried out to check the reliability of the translated questionnaires. The questionnaires were administered on persons with dizziness and the score was later exposed to item analysis by means of Cronbach's alpha test; results revealed a value of 0.78 for DHI and 0.88 for VAP. The data obtained from all participants were analyzed to investigate how quality of life (as measured by the severity of handicap reported by the DHI items) depended on activity limitations and participation restrictions (as measured by VAP). Statistical Package for Social Sciences (SPSS) software, version 19 was used to carry out the statistical analyses.

\section{Results}

Audiovestibular results revealed heterogeneous vestibular disorders in the studied 56 participants who had a dizziness complaint. Among them, 15 individuals had Meniere's disorder, 20 had BPPV, and 16 had unspecified peripheral vestibular pathology. Central vestibular problem due to

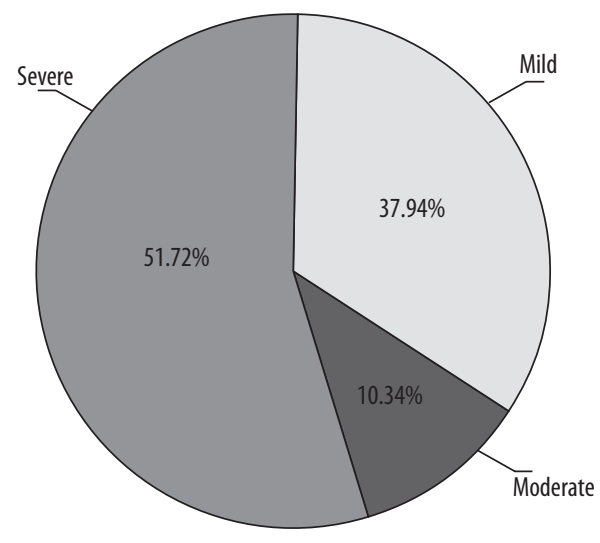

Figure 1. Distribution of patients according to the selfperceived severity of their handicap

degeneration of the vestibular system was suspected in 5 individuals (Table 1).

\section{Self-perceived handicap}

Analysis of the degree of handicap based on the scores obtained from the DHI (Marathi version) revealed that the self-perceived handicap varied from mild to severe across all participants. The mean total score was 44.94 with a standard deviation (SD) of 25.91. Based on the classification given by Jacobson [4], individuals were further classified into a mild, moderate, or severe category of self-perceived handicap. It can be seen from Figure 1 that a majority of individuals (52\%) had a severe handicap, $32 \%$ had a mild handicap, and $10 \%$ had moderate self-perceived handicap.

Table 2 shows the self-perceived handicap on the different subscales/domains of DHI. It can be observed that the severity of handicap reported in the physical domain was highest, followed by the functional and emotional domains.

\section{Levels of activities and participation}

Levels of activities and participation in individuals with dizziness was assessed using the Marathi version of VAP. Figure 2 shows the mean and SD values for each question of VAP for the studied population. The mean values varied 
Table 2. Mean and SD of various domains of DHI scale $(n=56)$

\begin{tabular}{lcr}
\hline DHI & Mean & Std. deviation \\
\hline DHI total & 44.94 & 25.91 \\
\hline Physical & $13.84(44.9 \%)$ & $8.05(31.1 \%)$ \\
\hline Emotional & $17.47(41.9 \%)$ & $9.00(26.5 \%)$ \\
\hline Functional & $16.31(42.8 \%)$ & $31.06(31.1 \%)$ \\
\hline
\end{tabular}

Max score: 100 for DHI total, 28 for physical, 36 for emotional, 36 for functional.

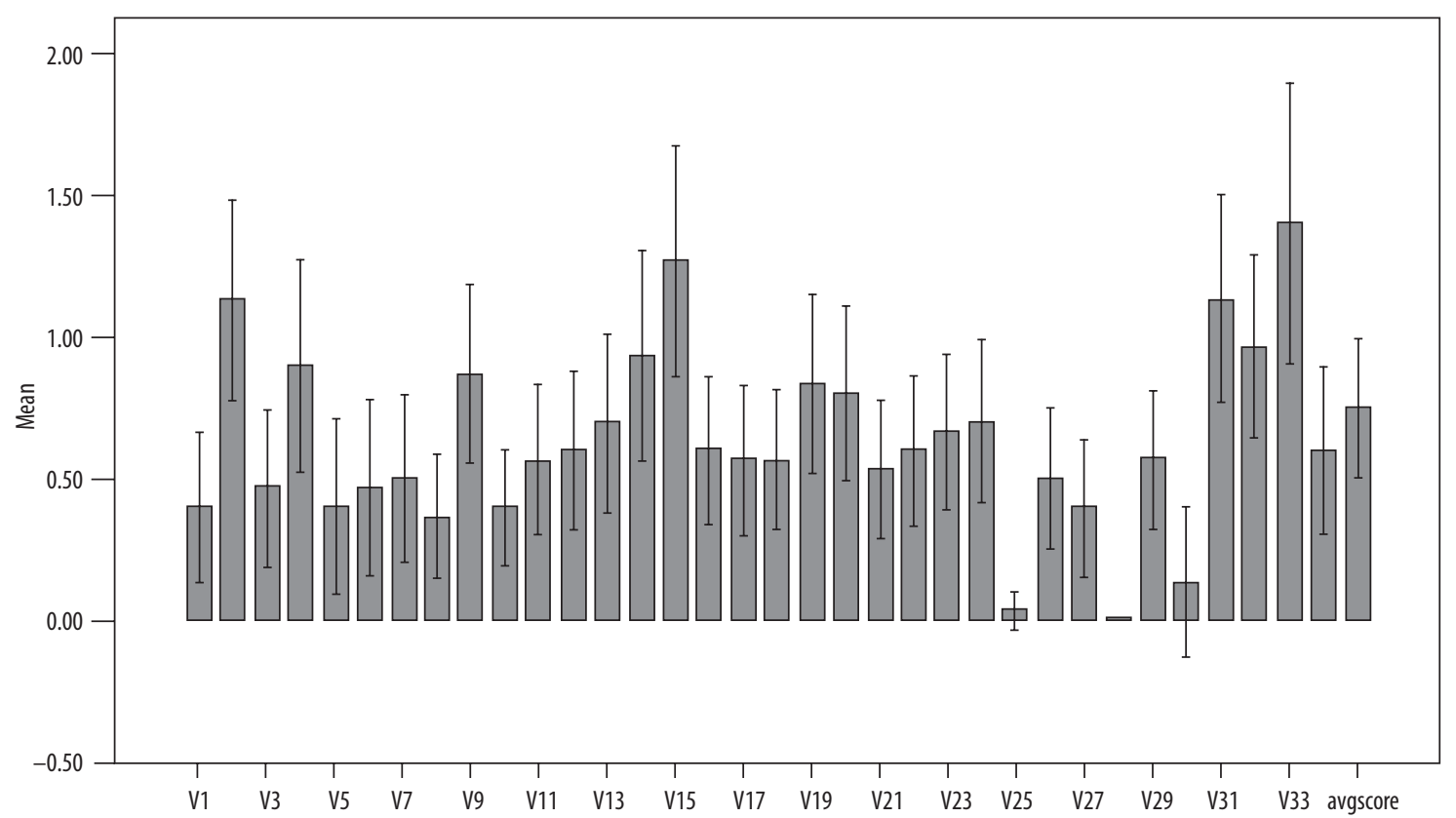

Figure 2. Mean and SD values for each question of VAP. Error bars show \pm 2 SE

from 0.03 to 1.80 across different questions of VAP scale. Out of the 34 questions of the VAP, the largest scores were observed for questions $2,4,9,14,15,24,31,32$, and 33 .

\section{Association between DHI and VAP}

Shapiro Wilk's test was applied to the whole data in order to investigate whether the data was normally distributed. As the $p$ values for most items on both questionnaires were less than 0.05 , a nonparametric test of correlation coefficient, Kendall's tau, was used to investigate whether there was an association between each item of the DHI scale and the total VAP score. The results revealed that 12 questions showed a significant and moderate correlation with the total VAP score, while 8 questions showed significant but weak correlation, and 5 questions showed a poor correlation (Tables 3 and 4).

\section{Discussion}

In the present study, self-perceived handicap and vestibular activity limitations and participation restrictions were studied in individuals with dizziness using Marathi versions of the DHI and VAP. The DHI results indicated that in persons with dizziness, the physical domain is maximally affected, followed by the functional domain and the emotional domain. These findings are consistent with reports of other investigators who found that self-perceived handicap in individuals with dizziness is determined most often by the physical and functional domains [12-17]. Physical aspects such as the inability to make any changes in the position of head, or an increase in dizziness in certain situations such as walking on a narrow street, are experienced most often due to dysfunctioning or impairment of the vestibular sensory organ and its pathways which are required for maintaining balance. It has been reported that various vestibular pathologies such as BPPV, Meniere's disease, and vestibular neuritis, which result into impairment of the peripheral vestibular organ, affect the physical domain more than any other domain [18].

Impairment of the vestibular system has a direct effect on day-to-day living as it limits the ability to perform many daily tasks $[5,12]$. Functional aspects such as walking alone in darkness, participating in social functions, and staying alone at home are affected due to impairment of vestibular reflexes. As a result, a person with dizziness will hesitate to go out alone, or may not have enough confidence to drive or travel alone, thereby affecting the functional domain more. The scores obtained in the present study for the functional domain of DHI reinforce these earlier reports in the literature $[13,14,16]$. 
Table 3. DHI items that had a moderate correlation with the total VAP score

\begin{tabular}{|c|c|c|}
\hline Brief description of question & Question No. & VAP score \\
\hline Getting in/out of bed (F) & DHI 5 & $0.511^{\star *}$ \\
\hline Restricted social activity (F) & DHI 6 & $0.521^{\star *}$ \\
\hline Difficulty reading (F) & DHI 7 & $0.503^{* *}$ \\
\hline Leave home alone (E) & DHI 9 & $0.495^{* *}$ \\
\hline Embarrassed (E) & DHI 10 & $0.612^{* *}$ \\
\hline Quick head movement $(P)$ & DHI 11 & $0.469^{\star *}$ \\
\hline Avoid height (F) & DHI 12 & $0.487^{* *}$ \\
\hline Turn in bed $(P)$ & $\mathrm{DHI} 13$ & $0.549^{* *}$ \\
\hline Walk by yourself (F) & $\mathrm{DHI} 16$ & $0.561^{* *}$ \\
\hline Depressed (E) & DHI 23 & $0.539^{* *}$ \\
\hline Job/home responsibilities (F) & DHI 24 & $0.567^{* *}$ \\
\hline Bending over $(P)$ & $\mathrm{DHI} 25$ & $0.560^{\star *}$ \\
\hline
\end{tabular}

* Significant at $0.05 ;{ }^{* *}$ significant at 0.01 .

Table 4. DHI items that had a weak correlation with the total VAP score

\begin{tabular}{lll}
\hline Brief description of question & Question No. & VAP score \\
\hline Looking up (P) & DHI 1 & 0.283 \\
\hline Frustrated (E) & DHI 2 & $0.437^{* *}$ \\
\hline Restricted travel & DHI 3 & 0.358 \\
\hline Walk in aisle (P) & DHI 4 & 0.271 \\
\hline Ambitious activity like sports (P) & DHI 8 & $0.392^{* *}$ \\
\hline Strenuous housework (F) & DHI 14 & $0.426^{* *}$ \\
\hline Appear intoxicated (E) & DHI 15 & $0.386^{*}$ \\
\hline Walking on sidewalk (P) & $0.403^{\star *}$ \\
\hline Difficult concentration (F) & DHI 17 & $0.381^{* *}$ \\
\hline Walk in dark (P) & DHI 18 & $0.445^{* *}$ \\
\hline Stay home alone (E) & DHI 19 & 0.298 \\
\hline Handicapped (E) & DHI 20 & 0.286 \\
\hline Stressed relations (E) & DHI 21 & $0.344^{*}$ \\
\hline
\end{tabular}

* Significant at $0.05 ;{ }^{* *}$ significant at 0.01 .

The emotional domain has been found to be least affected in the present study. Emotional reactions are reported to be less affected in individuals with dizziness than the physical and functional domains as any abnormality in this element is normally the result of physical limitations and long-lasting functional disabilities that affect social, familial, and professional life [19-21].

Furthermore, analysis of the VAP scale showed that the levels of participation varied depending on the activity or situation. It was observed that persons with dizziness had greater difficulty during certain activities such as sports, changing positions, lifting and carrying objects, carrying out daily routine, reaching overhead, using transportation, and doing household work. It was observed that activities essential for every-day life and demanding greater eye-hand coordination, body orientation, and postural stability were affected.
The activities for which the participants demonstrated moderate difficulty were operating a vehicle, preparing meals, walking long distances, walking on different surfaces, shopping, and vocational training. Similarly, other tasks such as assisting household members with self-care, moving around within the home, moving around or within buildings, moving around using equipment, and washing the whole body were also moderately affected. These activities are observed to be less affected than others, probably due to the pathology associated with the subject or due to the lesser demand in the studied subjects to perform the above activities in day-to-day life. A majority of the participants in the present study had peripheral vestibular pathology: Meniere's disease or BPPV. It has been known that BPPV has most effect on activities that involves active head movements. Secondly, individuals with Meniere's disease have episodic vertigo which may last several hours and resolve on its own. Thus many participants had less 
difficulty in walking long distances or on uneven surfaces, preparing meals, etc. Similarly, driving, shopping, and vocational training were not commonly encountered conditions among the participants of the present study, meaning they were less severely affected in this regard.

Correlation analysis revealed that some of the items of DHI showed a significant moderate correlation, whereas some questions had a weak correlation or no correlation with total VAP score. It can be inferred therefore that not all the questions relating to the physical, functional, or emotional domains relate to activity limitations encountered in day-to-day life. The present results are partially in agreement with the reports of earlier investigators who have grouped the DHI questions into disability and handicap categories $[22,23]$. Many of the questions which were found to be associated significantly with VAP in the present study were categorized under the handicap category by a previous researcher [9]. However, there are many items in the physical domain which were found to be significantly correlated in the present study but which were not considered important for determining quality of life in the earlier study [22-24].
Similarly, an earlier study reported that several questions - feeling depressed, embarrassed, inability to perform job/ home responsibilities, restricted social relationships, or inability to walk alone - more strongly indicate an impaired quality of life than do other questions on DHI, and may therefore also point to participation restrictions due to vestibular impairment [10]. However in the present study it was found that a few questions -such as feelings of handicap, frustration, and inability to walk in the dark - were not significantly associated with VAP. Discrepancies in the present results might be attributed to variations in the participants themselves such as vestibular pathology, age, occupation, and socio-cultural background. The results of the present study support the suggestion of earlier investigators that there is a need to restructure DHI [10].

\section{Conclusions}

Although DHI was designed to measure perceived handicap due to dizziness, some of the items of the DHI actually represent limitations due to vestibular factors. The results indicate that the items which have a significant correlation with VAP are more relevant to the quality of life of people with dizziness. These items should become the focus when studying improvements in the quality of life after rehabilitation.

\section{References:}

1. Boult C, Murphy J, Sloane P, Mor V, Drone C. The relation of dizziness to functional decline. J Am Geriatr Soc, 1991; 39: 838-61.

2. Cohen H, Kane-Wineland M, Miller L, Hatfield C. Occupation and visual/vestibular interaction in vestibular rehabilitation. Otolaryngol Head Neck Surg, 1995;112: 526-32.

3. Ganança FF, Castro ASO, Branco FC, Natour J. Impact of dizziness on the quality of life in patients with peripheral vestibular dysfunction. Rev Bras Otorrinolaringol, 2004; 70(1): 94-101.

4. Jacobson GP, Newman CW. The development of the Dizziness Handicap Inventory (DHI). Arch Otolaryngol Head Neck Surg, 1990;116: 424-7.

5. Whitney SL, Wrisley DM, Brown KE, Furman JM. Is perception of handicap related to functional performance in persons with vestibular dysfunction? Otol Neurotol, 2004; 25(2): 139.

6. Andersson G, Asmundson GJG, Denev J, Nilsson J, Larsen HC. A controlled trial of cognitive-behavior therapy combined with vestibular rehabilitation in the treatment of dizziness. Behaviour Research and Therapy, 2006;44: 1265-73.

7. Johansson M, Akerlund D, Larsen HC, Andersson G. Randomized controlled trial of vestibular rehabilitation combined with cognitive-behavioral therapy for dizziness in older people. Otolaryngol Head Neck Surg, 2001; 125: 151-6.

8. Perez N, Garmendia I, Garcia-Granero M, Martin E, GarciaTapia R. Factor analysis and correlation between Dizziness Handicap Inventory and dizziness characteristics and impact on quality of life scales. Acta Otolaryngol Suppl, 2001; 545: $145-54$.

9. Kurre A, Bastiaenen CH, van Gool CJ, Gloor-Juzi T, de Bruin ED, Straumann D. Exploratory factor analysis of the Dizziness Handicap Inventory (German version). BMC Ear Nose Throat Disord, 2010; 10: 3.
10. International Classification of Functioning, Disability and Health. [http://www.who.int/classifications/icf/en/], 30.01.2010.

11. Alghwiri AA, Whitney SL, Baker CE, Sparto PJ, Marchetti GF, Rogers JC. The development and validation of the vestibular activities and participation measure. Arch Phys Med Rehabil, 2012; 93: 1822-31.

12. Castro AS, Gazzola JM, Natour J, Ganança FF. Brazilian version of the dizziness handicap inventory. Pro Fono, 2007;19: 97-104.

13. Enloe LJ, Shields RK. Evaluation of health-related quality of life in individuals with vestibular disease using disease-specific and general outcome measures. Phys Ther, 1997: 890-903.

14. Asmundson GJ, Stein MB, Ireland D. A factor analytic study of the dizziness handicap inventory: does it assess phobic avoidance in vestibular referrals? J Vestib Res, 1999; 9: 63-8.

15. Gámiz MJ, Lopez-Escamez JA. Health-related quality of life in patients over sixty years old with benign paroxysmal positional vertigo. Gerontology, 2004; 50(2): 82-6.

16. Ten Voorde M, van der Zaag-Loonen HJ, van Leeuwen RB. Dizziness impairs health-related quality of life. Quality of Life Research, 2012; 21: 961-6.

17. Duracinsky M, Mosnier I, Bouccara D, Sterkers O, Chassany O. Working Group of the Société Française d'Oto-Rhino-Laryngologie (ORL). Literature review of questionnaires assessing vertigo and dizziness and their impact on patients' quality of life. Value Health, 2007;10: 273-84.

18. León VV, Gutiérrez V, Hurtado CE, Ramirez-Velez R. Relationship between health-related quality of life and disability in women with peripheral vertigo. Acta Otorrinolaringol, 2010; 61: 255-61.

19. Grimby A, Rosenhall U. Health-related quality of life and dizziness in old age. Gerontology, 1995; 41(5): 286-98. 
20. Handa RR, Kuhn AM, Cunha F, Schaffleln R, Ganança FF. Quality of life in patients with benign paroxysmal positional vertigo and/or Ménière’s disease. Braz J Otorhinolaryngol, 2005; 71: 776-82.

21. Yardley L, Putman J. Quantitative analysis of factors contributing to handicap and distress in vertiginous patients: A questionnaire study. Clin Otolaryngol Allied Sci, 1992; 17(3): 231-6.

22. Grill E, Furman JM, Alghwiri AA, Müller M, Whitney SL. Using core sets of the international classification of functioning, disability and health (ICF) to measure disability in vestibular disorders: study protocol. J Vestib Res, 2013;23(6): 297-303.
23. Alghwiri AA, Marchetti GF, Whitney SL. Content comparison of self-report measures used in vestibular rehabilitation based on the international classification of functioning, disability and health. Phys Ther, 2011; 91(3): 346-57.

24. Alghwiri A, Alghadir A, Whitney SL. The vestibular activities and participation measure and vestibular disorders. J Vestib Res, 2013; 23(6): 305-12. 